Research Report No. 18/2009

\title{
Legal Models and Business Realities of Enterprise Groups - Mismatch and Change
}

Kurt A. Strasser

Phillip I. Blumberg

Follow this and additional works at: http:/ / digitalcommons.osgoode.yorku.ca/clpe

\section{Recommended Citation}

Strasser, Kurt A. and Blumberg, Phillip I., "Legal Models and Business Realities of Enterprise Groups - Mismatch and Change" (2009). Comparative Research in Law \& Political Economy. Research Paper No. 18/2009.

http://digitalcommons.osgoode.yorku.ca/clpe/131 


\section{Comparative Research in Law \& Political Economy}

CLPE RESEARCH PAPER $18 / 2009$

\section{Kurt A. Strasser and Phillip I. Blumberg}

\section{Legal Models and Business Realities of Enterprise Groups- Mismatch and Change}

EDITORS: Peer Zumbansen (Osgoode Hall Law School, Toronto, Director, Comparative Research in Law and Political Economy, York University), John W. Cioffi (University of California at Riverside), Nassim Nasser (Osgoode Hall Law School, Toronto, Production Editor) 

CLPE Research Paper 18/2009

Vol. 05 No. 03 (2009)

Kurt A. Strasser and Phillip I. Blumberg

\title{
Legal Models and Business Realities of Enterprise Groups-Mismatch AND ChANGE
}

\begin{abstract}
Although conducted world-wide through hundreds of subsidiaries and affiliates, modern large business is, in economic reality, typically a single economically integrated enterprise functioning with a common objective under the control of its parent company. Yet the prevailing legal models are, for the most part, oblivious to this. Mistakenly adopting outmoded concepts inherited from the misty past, these models focus on many separate subsidiary corporations that make up the business and necessarily overlook the larger whole. The result of this outdated view is a mismatch between business reality and legal form which has led so frequently to poor legal and regulatory decision-making and ineffectual public control. While there is change stirring today, overall the law's response to this mismatch has been piecemeal and unsystematic. After reviewing how we got to this unhappy point, this paper will sketch out a new legal theory of enterprise analysis as the basis of modern corporation law to serve the needs of the Twenty-First Century. In some areas it will replace and in other areas it will supplement existing legal models. Enterprise analysis focuses on the implementation of the underlying policies and rules of the specific body of law at issue, such as securities, tax, or bankruptcy, to determine whether the objectives of that body of law are better served in the specific matter by looking to the whole enterprise or, alternatively, to the particular corporate subsidiary entities involved. While overt recognition of this enterprise analysis has been limited, the American legal system today is in fact applying it in numerous areas.
\end{abstract}

Keywords: Corporate limited liability, corporate groups, multinational companies, shareholder liability, enterprise liability

JEL classification: K22, K13, L22, L53 


\author{
Kurt A. Strasser \\ Phillip I. Blumberg Professor \\ University of Connecticut Law School \\ 65 Elizabeth St. \\ Hartford, Ct. 06109 \\ USA \\ Kurt.strasser@law.uconn.edu
}

Phillip I. Blumberg

Professor Emeritus of Law and Business

University of Connecticut Law School

65 Elizabeth St.

Hartford, Ct. 06109

USA

Phillip.Blumberg@law.uconn.edu 


\title{
LEGAL MODELS AND BUSINESS REALTIES OF ENTERPRISE GROUPS- MISMATCH AND CHANGE
}

\author{
Kurt A. Strasser and Phillip I. Blumberg*
}

\section{Introduction.}

It is accurate, but commonplace, to note that large businesses today are vast organizations of wide scope and immense wealth and power. In our increasingly globalized world, multinational businesses span many countries. One can rent a car from Hertz in Amsterdam or Paris and deal with what is apparently the same business as in Hartford, Connecticut. The corporate persona is the same, complete with matching logo and color scheme, coordinated operations and advertising, and consistent rental terms. Similarly, one can rent a hotel room from Hilton and do business with the same company, using the same corporate persona, which one can find literally all over the world. These are each single business enterprises, with common management control and a high degree of economic integration (Muchlinski 2007, chap. 1). The consumer believes that he or she is dealing with Hertz or Hilton where in fact she is dealing with a subsidiary, often a third or fourth-tier subsidiary, or a franchisee or other affiliate of Hertz or

\footnotetext{
${ }^{\circ}$ Eric King provided invaluable research assistance in preparation of this paper.

* Kurt A. Strasser is the Phillip I Blumberg Professor of Law at the University of Connecticut Law. Professor Strasser co-authored the second edition of Blumberg on Corporate Groups (5 vols, with Blumberg, Georgakopoulas, and Gouvin) as well as three volumes of the first edition. He earned a BA (1969) and a JD (1972, Order of the Coif) from Vanderbilt University, and a JSD from Columbia University (1986). He joined the University of Connecticut Law School faculty in 1981 and has taught there since that time, serving as Associate Dean for Academic affairs from 1996-99 and as Interim Dean for academic year 2006-07. He has twice been a Visiting Professor at Exeter University in England, served as the DAAD Guest Professor of Anglo-American Law at the Free University of Berlin in the summer of 2003, and servee as the Gilhuis Professor on the Future of Environmental Law at Tilburg University during the spring of 2008. He is a member of the Connecticut and Tennessee bars. In addition to authoring publications in numerous academic journals, he was the Reporter for the Uniform Environmental Covenants Act which was adopted by the National Conference of Commissioners of Uniform State Laws in 2003. http://www.law.uconn.edu/faculty/kstrasse/

Phillip I. Blumberg, A.B. Harv., J.D. Harv., LL.D. Conn. (hon.) Is Dean and Professor of Law and Business, Emeritus, The University of Connecticut School of Law. For decades, he has studied the legal problems presented by multinational and other large corporations. His seven volumes in the series on The Law of Corporate Groups (1983-98) since replaced by Blumberg on Corporate Groups (Second Edition, 2005-2008) written with Profs. Kurt A. Strasser, Nicholas Georgakopoulos, and Eric Gouvin have attracted world-wide attention. He has written other books, including The Multinational Challenge to Corporate Law (1993) and The Megacorporation in American Society (1975). He has published several dozen articles in legal periodicals and has presented papers at international conferences on multinational corporations in England, Italy, and Australia. He has taught at Boston University School of Law and at universities in The Netherlands, Poland, and Australia. He is a member of the American Law Institute and has served as an Advisor in three A.L.I. Restatements (Corporate Governance, Suretyship, and Agency). He has also served on the Legal Advisory Committee of the New York Stock Exchange. http://www.law.uconn.edu/faculty/pblumber/
} 
Hilton. Enterprise analysis provides a Twenty-First Century answer to whether for legal purposes the customer is deemed to be dealing with Hertz or Hilton or its affiliate.

Of course, these enterprises may choose to allow their local operations a substantial degree of local initiative, but each is still one enterprise under the direction of the parent corporation. The local initiative provided is chosen as a management strategy by those controlling the enterprise, not as the real partitioning of the business into genuinely separate operating entities.

This unitary character of large business enterprises is well established and remarking on it is neither novel nor surprising. What is genuinely surprising is that modern corporate law has such a difficult time recognizing this most obvious business reality in many situations. Traditional legal thinking starts with legal form, not business reality, and the traditional legal form of the modern business is typically not one unitary entity. Rather, the legal form today is most often a commonly owned and managed combination of many nominally separate corporations, through a parent corporation and successive tiers of sub-holding corporations. Legal thinking starts from the outdated model that each corporation is a separate entity, and the legal mind is often unable to escape this self imposed conceptual snare to look at the real business entity. The result is a legal view of the business enterprise which bears little relation to its underlying economic reality.

The focus on separate corporate entities, rather than the real business enterprise, can have particularly unfortunate consequences in view of an important legal corollary to the model of corporate separateness, the theory of limited liability for shareholders. Thus, the legislature has established a general policy that shareholders are not liable for the obligations of their corporations. Limited shareholder liability was adopted after a political struggle by legislatures seeking to respond to the need of the small businesses of the day to raise increasing amounts of capital in order to take advantages of the burgeoning opportunities opening under the advanced Industrial Revolution. This limited shareholder liability was originally developed for the simpler economic era of those times in the early and mid-19th Century when corporations were small, shareholders were few and parent corporations, holding companies, and subsidiaries, were legally unavailable and unknown. At that time, enterprises were not made up of groups of corporations controlled by a common parent. Today, enterprises are made up of such groups of corporations and the legal doctrines developed to serve the needs of that different era have become manifestly dysfunctional. Whatever limited liability's contemporary merits for shareholders who hold the public shares of the modern corporation ${ }^{1}$, it makes no sense for that parent company itself even though it is the shareholder of its subsidiary corporations in the modern corporate group. Yet our dysfunctional anachronistic law still typically starts with this presumption of corporate separateness and limited liability within corporate groups. While the inadequate corollary doctrine of "piercing the veil" is theoretically available as a constraint of

\footnotetext{
${ }^{1}$ Limited liability for investor shareholders is controversial in contemporary academic discussion, although that controversy is beyond the topic of this paper. See Michael (2000, pp. 48-53), discussing the different strengths of the rationale for limited liability in contract and tort cases. Hansmann and Kraakman (1991) argue that pro rata shareholder liability should be the rule for tort cases. See generally Blumberg, Strasser, Georgakopoulos and Gouvin $(2005, \S 66.01,66.06)$.
} 
limited liability, the doctrine is universally condemned as confusing and failing to provide an adequate guide for judicial decision. The result of applying models of corporate separateness and limited liability to modern corporate groups is, all too often, legal and regulatory decision making which reaches poor results in resolving disputes and imposing public regulatory controls.

How did we arrive at this conceptual mess? This paper will briefly sketch the history of corporate law to argue that, for the most part, the law failed to account for the functional economic difference between investor shareholders and parent company shareholders. When in the late nineteenth and early twentieth century, corporate "reform" permitted parent corporations for the first time to own subsidiary corporations and thus allowed the creation of corporate groups as the primary form of business organization, courts were presented with a fundamental question: what rules should govern the legal interrelationships of the now permissible parent and subsidiary corporations. Unfortunately, no court recognized the challenge of crafting a new analysis and the new rules which were needed for this new situation. Instead, courts applied existing rules which had been crafted for an entirely different economic reality, and thus this decision of profound implications for the economy was made purely formally, with no consideration of the new economic structure of business and its social implications. Courts reasoned that shareholders had no legal responsibility for the debts of their corporations; a parent corporation was a shareholder; ergo, a parent corporation was not liable for the debts of its subsidiaries. No thought was apparently given to the business realities.

Yet this otherwise discouraging picture is more varied and nuanced, for some areas of law have successfully escaped the conceptual snare of the traditional models and broadened their vision to encompass the whole business enterprise, not stopping at the contours of the individual legal corporate form. This new model, which considers the whole business enterprise, has found substantial use in several modern regulatory systems and some traditional dispute resolution, although it has typically gone almost unrecognized as a new general model in the process. The new model is functional, not formal; it is based on the business reality of corporate groups as enterprises, and on enterprise analysis which looks to the rules and policies of the area of law involved, such as tax, bankruptcy, etc, to determine whether legal decision making and legal liability should consider the whole business enterprise or only part of it. An enterprise analysis stresses that the critical standard is whether an enterprise or an entity view will implement those underlying policies or result in their frustration. We will conclude the paper with a sketch of this enterprise analysis and a review of some illustrative applications, arguing that enterprise analysis calls for looking to the whole business where doing so better accomplishes the policies and goals of the area of law involved. 


\section{THE TRADITIONAL LEGAL MODEL: SEPARATE CORPORATE ENTITY AND LIMITED SHAREHOLDER LIABILITY.}

As business enterprise transformed early in the $19^{\text {th }}$ century from 1800 to 1850 , with the increasing popularity of use of the corporate form for the conduct of business activities the states enacted general incorporation statutes allowing investors to freely organize corporations to conduct most forms of business. Thus, much of American business was conducted by the newly created corporate legal entity possessing a legal status and personality separate from its shareholders (Blumberg, Strasser, Georgakopoulos \& Gouvin et al., 2005, chap. 2). ${ }^{2}$ This legal status included the right to contract, buy and sell property, operate a business, and incur liability separate from its shareholders.

Along with this development, business forces pressing for more and more capital to take advantage of the technological advances of the Industrial Revolution thereupon sought limited liability for their investors. By making shareholders generally not liable for the obligations of the corporation, the law would encourage investors to provide capital for the growing enterprises. In the political struggle over the adoption of this new principle, business argued that individual shareholders in the corporations of the day were primarily investors, not participating directly in management and with only incomplete power to supervise the activities of the increasingly larger and more professionally managed business of the corporation. Business argued that if shareholders couldn't supervise in detail, and the corporation was separate anyway, shareholders shouldn't be generally liable for its activities. The argument generally prevailed and the result was that shareholders became protected by limited liability. This fundamental policy is the basis of public securities markets today, and is in no way challenged by enterprise analysis. Enterprise analysis concerns only whether this protection of limited liability should be afforded to parent corporations within the corporate group.

Of course there were limits to limited liability for shareholders. The courts devised the doctrine of "piercing" or "lifting the veil" to deal with "exceptional cases". This is a theory familiar to all common law lawyers, which authorizes shareholder liability in the "exceptional" situation where the corporation is not really separate, or when the corporate form is abused. ${ }^{3}$ Readers from Civil Law jurisdictions will doubtless recognize similar problems and analogous doctrines. ${ }^{4}$ But

\footnotetext{
${ }^{2}$ Limited liability came to New England in the 1830, Act of Feb. 23, 1830, ch. 53, §8, 1830 Mass Acts 325, 329 (Dodd, 1960, pp. 378-381), the UK in 1855, but remarkably not until 1930 in California, Cal. Const. of 1849, art. IV, §36; Cal. Const. of 1879, art. XII, §§3, 15 (replaced 1931); Cal. Civ. Code 322 (repealed 1931) (Muchlinski, 2007). See Blumberg (1993) for a review of the history of the idea of corporate separateness.

${ }^{3}$ This theory is much maligned in the common law academic literature. Perhaps the most quoted criticism is from Easterbrook and Fischel (1985) " 'Piercing' seems to happen freakishly. Like lightning it is rare, severe, and unprincipled." See Bainbridge (2001). However, it continues to be the primary approach applied by courts.

${ }^{4}$ For an excellent introduction, see Antunes (1994, pp. 250-258). In general, relief from limited shareholder liability is similarly restricted to unusual situations, often based either on specific statutory provisions for insolvency, or on vague doctrines emphasizing "abuse" or, in Italian law, "tyrant" shareholders.
} 
limited liability for shareholders was and remains the norm, and shareholder liability is conventionally thought to be an unusual result which is called for only in "exceptional" or "extraordinary" circumstances.

The modern justification for limited shareholder liability argues that it facilitates investment by investor shareholders, and thus capital formation for society, by reducing three types of transaction costs. ${ }^{5}$ First, it reduces cost by removing the need for shareholders and creditors to monitor the solvency of other shareholders, something they would otherwise need to do to evaluate the extent of their own potential liability. Second, limited liability reduces the need for shareholders and creditors to monitor management to ensure that the corporation's managers are not engaged in excessively risky business activities and thereby exposing shareholder's personal assets to excessive risk. Third, the argument runs, limited liability facilitates ownership of more diversified portfolios by investors because diversification in the form of owning shares in more companies does not expose their personal assets to a greater risk of liability. ${ }^{6}$ These justifications for limited liability emphasize the role of investor shareholders. They simply do not sensibly apply to parent company shareholders in modern corporate groups.

In the modern corporate group, the investor shareholders own the parent company, and the parent company owns the shares of the subsidiaries. The whole group of corporations, both parent and subsidiaries, is in reality one business enterprise, operating under the unitary control of the parent and possessing a high degree of economic integration. Interdependence of the business functions is its hallmark in administration, finance, employee selection and management, and use of the corporate public persona (Blumberg et al., 2005, chap. 6; Muchlinski, 2007, chap. 2; Antunes, 1994, chap. 4). As noted above, where the parent allows substantial independence of initiative or action to specific operating units, doing so is a strategic management decision made by those in charge of the whole enterprise, and one which can of course be changed as senior management of the parent chooses. This is true regardless of the legal form or internal designation of the operating unit, whether it is a separate corporate subsidiary, an operating division, or some other internally defined unit. The parent company shareholder is not in the same economic or functional role as an individual investor shareholder and the justifications for limited liability for the latter do not apply to the former.

Specifically, the transaction cost justifications for limited liability are not applicable to a parent company shareholder. First, the parent need not monitor the assets of its fellow shareholders to

\footnotetext{
${ }^{5}$ The classic modern statements are Easterbrook Fischel (1994), and Ribstein (1991). Excellent recent summaries are in Bainbridge (2001, pp. 487-506), and Mendelson (2002, pp. 1217-1247). In addition, Hansman and Kraakman (2000) have developed a most interesting theory of asset partitioning, which argues that limited liability serves important social interests by guaranteeing to creditors that business assets will also be protected from investors' creditors.

${ }^{6}$ See authorities cited supra n. 1.
} 
determine its contingent liability. Indeed, it frequently owns $100 \%$ of the subsidiary and there are no other shareholders. ${ }^{7}$ The second transaction cost justification-monitoring management-doesn't fit either. The controlling parent company shareholder is making the decisions about the relative riskiness of the business operations to undertake and it has no need to further monitor its own decisions in order to limit its liability, so it would incur no extra cost in doing so. The third justification, reducing the costs of diversification, similarly fails. The parent company is an operating entity and, as such, it does not have the investors' interest in diversifying its investments. Investors diversify to spread risk among investments. While the parent company may choose to diversify the businesses within its enterprise, it can do so as an internal management decision, one which will have operating costs and benefits quite different from those involved in investment diversification. Thus it can choose to include diverse businesses within its enterprise, but doing so will require decisions about operating those businesses and integrating them which are simply not presented to an investor seeking to diversify. These will be the costs and benefits of a management decision and in principle that decision should not turn on limited liability, but on operating factors. In sum, the justifications for limited liability for investor shareholders simply don't fit the economic reality of parent companies as shareholders. (Antunes, 1994 pp. 113-155)

Why, then, do the courts routinely apply it? More generally, why do legal thinkers treat subsidiaries as if they are separate and unrelated entities from their controlling parent companies? The answer comes from the overlap of a rule change in corporate law and the court's original and continuing failure to appreciate it. As noted above, operating a business through the corporate form came to be generally allowed and accepted from roughly 1800 to 1850 , and the enactment of limited liability for shareholders followed thereafter. Yet, at that time, corporations were not generally permitted to own shares in other corporations (Blumberg et al., 2005, chap. 5). As a result, corporate groups with parent and subsidiaries could not exist. Indeed, in that simpler era, each corporation was much more likely to actually be a separate operating enterprise because it could not subdivide itself into numerous corporate subsidiaries which were legally separate.

The key legal change came later, soon after 1890, when the law changed and corporations were generally allowed to own shares in other corporations. ${ }^{8}$ In relatively short order the current structure of modern large business emerged, with a parent holding company controlling the enterprise through its ownership of the shares of its subsidiaries. The result is the structure we see commonly today. As part of this change, corporations became much larger, with many more shareholders, and professional management separate from the shareholders. Yet when this change happened, courts did not adjust the application of rules of limited liability to this changed

\footnotetext{
${ }^{7}$ When there are non-controlling minority shareholders, they do not manage the enterprise and their interest receives the limited protection it gets only as they are treated as investors.

${ }^{8}$ New Jersey was the first to change its law, from 1889-1893. Act of Apr. 4, 1888, ch. 269, §1, 1888 N.J. Laws $385-$ 56; Act of Apr. 17, 1888, ch. 295, §1, 1888 N.J. Laws 445-46; Act of May 9, 1889, ch. 265, §4, 1889 N.J. Laws 412, 414; Act of Mar. 14, 1893, ch. 171, §2, 1893 N.J. Laws 301. Virtually all other US jurisdictions followed.
} 
business reality. Although controlling parent companies, as shareholders, are in a fundamentally different position from investor shareholders, with fundamentally different roles in managing the business, the courts failed to perceive this difference; instead, courts applied to parent companies the same rules of limited liability based on the same principles of corporate separateness. As a result, parent companies were able to use layers of subsidiaries to effectively insulate themselves from much of the liability which could arise from operating their business enterprises (Blumberg, 2005; Blumberg et al., 2005, chap. 3). Legal thinkers today, including courts, generally hold that subsidiary corporations are separate entities and that their parent company shareholders should have the same limited liability as investor shareholders. Along with these traditional rules of separateness and limited liability have most frequently come the same exceptions, primarily "piercing the veil" and analogous civil law doctrines discussed above. We need a different theory for modern business organized in corporate groups-enterprise analysis.

The result of this fundamental misconception of the legal nature of business enterprise is often poor legal and regulatory decision-making. For example, consider the US Supreme Court's relatively recent decision on environmental contamination cleanup liability in the Bestfoods case. There, the Court interpreted the applicable statute, the Comprehensive Environmental Response Compensation and Liability Act, to call for "classic piercing" in all its severity without any inquiry about the impact of this decision on the statute's effectiveness (United States v. Bestfoods, Inc., 1988). In doing so, the Court made the decision of liability throughout the enterprise turn on traditional notions of corporate separateness for subsidiaries which had nothing to do with the public policy of environmental law. The Court did not inquire whether implementation of the statute's environmental contamination cleanup purpose called for treating the parent and subsidiary corporations as one enterprise, even if it meant bypassing the limitations of classic "piercing". Instead, the Court relied on a priori reasoning to conclude that Congress must have intended to apply the classic "piercing" doctrine. ${ }^{9}$ This is particularly unfortunate for it simply ignores one of the basic environmental law policies of the statute, that polluters are to pay for cleanup. As result, the liability of parent companies for environmental cleanup responsibilities of parts of their business conducted by subsidiaries will not be determined by application of the publicly determined policy of the underlying statute-polluter pays. Rather, parent company liability will be determined by traditional "veil piercing" tests, themselves often uncertain, which emphasize corporate formalities and are thus subject to manipulation by clever counsel. This is poor environmental policy and should also be poor corporate law. It results from applying deeply ingrained legal attitudes of corporate separateness and limited liability to subsidiaries where these concepts simply do not fit either the policy needs of modern law or the economic reality of modern corporate structure.

\footnotetext{
${ }^{9}$ The statute is silent on this point, concerned as it is with environmental policy rather than traditional corporate structure. When veil piercing is used, the court must decide whether to use federal or state law, and in this area federal law can potentially vary from traditional state rules. However, the court declined to answer this issue in Bestfoods, and the other authorities have been mixed (Blumberg et al., 2005, §99.03; §13.02).
} 
A second example, United States v. Elgin, Joliet and Eastern Railway (1996) shows similarly unfortunate results of failure to consider statutory policy in determining liability within an enterprise. The core regulatory policy at stake prohibited railroads from discriminating in price among different shippers, so as to afford equal treatment to all. The applicable statute prohibited railroads (in the statute called "carriers") from shipping their own goods because this had proven to be a particularly effective way of evading the price discrimination prohibition. Railroads, in response, transferred their coal and steel operations to newly organized subsidiaries to avoid the statute. When the government commission prosecuted the steel and coal subsidiaries for violation of the statute, the Court held that the statute applied to goods of "carriers" and that it did not apply to goods of a steel or coal company, even when it was owned and controlled by a "carrier". As a result, counsel was able to avoid the statute and frustrate the objectives of the Congress with the simple legal device of forming a subsidiary. ${ }^{10}$ The Court reasoned that the subsidiaries were separate legal entities, and thus not covered by the statutory language, although the separateness was only formal. The Court ignored the economic realities. As a commercial matter, the railroad was shipping its own goods when it shipped the goods of its wholly owned and controlled steel or coal subsidiary which operated as an integrated part of its railway system. Notwithstanding this reality, the Court accepted the purely formal separate existence of the subsidiary and its operations under the control of the parent of the railroad. It was satisfied by the separate forms, management by separate persons (although designated by the railroad) and separate assets (provided by the railroad or railroad funds). Legal form prevailed over economic substance, and the regulatory policy of the law was evaded.

These are, of course, only two examples; one could easily find many more. When legal thinking goes this far awry, one wonders why. More seems to be involved than just individual poor decisions by individual legal decision makers. We suggest that these kinds of results come from starting at the wrong place and then asking the wrong questions. Our solution is enterprise analysis, which starts at a different place and then asks different questions.

\section{ENTERPRISE ANALYSIS.}

Enterprise analysis takes a fundamentally different approach to determining the legal responsibilities within the modern business enterprises. It eschews the law's traditional starting point-that subsidiaries are separate entities because they are formally separate corporations. As argued above, this is not an accurate description of the business and economic reality of modern business enterprises. The legally separate subsidiaries are in fact part of a larger economic enterprise controlled by a parent company. We propose that legal decision making in this area, whether being done by courts, legislatures, or administrative agencies, start with this fundamental reality. Parent company shareholders are different from investor shareholders, they

\footnotetext{
${ }^{10}$ In other circumstances, courts have been willing to bypass veil piercing and interpret regulatory statutes to allow for regulating profits made in regulated transactions with corporate affiliates (United States v. New York Tel. Col, 1946; Schenley Distillers Corp. V. U.S., 1946; Blumberg et al., 2005, §§ 129.02, 129.05, 130.02[B]).
} 
perform different economic roles, and their legal rights and responsibilities should be determined by different rules. ${ }^{11}$ We need a new starting point for this new enterprise analysis.

The starting point for consideration should, then, be the actual operating business enterprise rather than the formal legal structures. If the legal entities are under common control and economically integrated, then we should start by thinking of them together as one enterprise. Control and integration are key; the details of internal division of power and responsibility, as with the details of formal legal separation, should not be determinative because they reflect strategic management decisions of those in control and can be changed as operating circumstances or liability exposure demand. In deciding that the group of corporations is one enterprise, as noted above, control and economic integration are fundamental. In addition, the extent of administrative and financial integration will be important indicators, as will employee selection and management. (Blumberg et al. 2005, chap. 6). Where the enterprise chooses to present itself as one business, using a consistent corporate persona, this will be an important indicator, although the failure to do so should count as no more than another strategic management decision.

Of course, determining the scope and boundaries of an enterprise can become complex in specific cases at the outer boundaries. The commonly owned and integrated corporate group we have been discussing presents few problems. But what of the enterprise formed by contract, such as a franchise system, rather than by ownership (Blumberg et al., 2005, chaps. 160-170, 175; Muchlinski, 2007, pp. 51-55)? Contractual enterprises can also take the form of joint ventures. Industry groups based on financial and other long-term commercial relationships, such as the Japanese "Keiretsu" will also present these questions (Muchlinski, 2007, pp. 63-65). In these and other cases of current and emerging new forms of business organization, enterprise analysis will have to contend with the difficult question of determining the scope of the enterprise. Although these specific cases will surely not be easy, they should be amenable to reasoned resolution by application of the basic principles of enterprise thinking to develop specific rules for new business structures as they emerge. Certainly, the difficulties this presents for the judiciary will be a pale shades of those it is experiencing today in applying traditional corporate law concepts to modern business enterprises.

Enterprise analysis rests on the pursuit of a fundamental legal policy by application of rules and principles to the business enterprise in the light of the surrounding economic realities. Thus, enterprise analysis requires legal thinkers seeking to determine the rights and duties of a parent and subsidiary company to be guided by the underlying policies and objectives of the specific area of the law in issue. Insofar as this particular corporate group with its particular pattern of control and integration is concerned, will the application of enterprise concepts rather than

\footnotetext{
${ }^{11}$ German law offers the most developed model of a system of corporate law based on the idea that corporate groups rather than individual corporate entities are the key element-the Konzernrecht. Use of this model is optional with the business. For an excellent introduction and discussion, see Antunes (1994, pp. 313-347). There have been a number of proposals for such a system in the EU (Antunes, 1994, pp. 277-294).
} 
traditional entity doctrines better implement those underlying legal policies and objectives? Is the application of enterprise concepts required to prevent facile frustration of those policies and objectives by the interposition of a subsidiary?

We are, after all, ultimately determining the scope of enterprise for a reason--to answer a question of allocating legal rights or legal responsibilities. Should the parent company be responsible for its subsidiary's environmental cleanup liabilities? Should banking regulation consider the financial soundness of non-banking subsidiaries as well as parent company banks? Should anti-fraud rules applicable to investment bank subsidiaries also apply to consulting subsidiaries? Should the operations of a subsidiary in one state, integrated with the operations of the parent in another, make the parent company subject to its judicial jurisdiction? These are all intrinsically legal questions and their answers should consider legal policies and rules as well as the underlying business reality. Corporate restructuring and corporate forms are lawyer's devices which can be used to defeat social policy in these and many other areas. Unless supplemented by enterprise analysis, entity law resting on the doctrine of the separate legal personality for corporate subsidiaries all too often has become dysfunctional. By ignoring the realities of large modern business structures, this entity law ceased to serve the needs of the $20^{\text {th }}$ and $21^{\text {st }}$ Century society.

A few examples will illustrate these points. In the Bestfoods case presented above, we argue, enterprise analysis quite properly posits that a parent company's liability for the environmental cleanup responsibility arising from the operations of its subsidiaries should finally be determined by the rules and policies of environmental cleanup law. Banking regulation, which seeks to insure financial soundness in order to protect the public from financial panic and disruption of bank failures, must reach past the formal lines of corporate separateness for subsidiaries to all the operations of the banking enterprise if it is to be effective. Otherwise, losses in one part of the enterprise can drain resources from the whole enterprise, and spread fear about it, to such an extent that the whole enterprise becomes unsound and fails. Anti-fraud rules must apply broadly, regardless of which subsidiary is the locus of the violation, if they are to actually protect investors and insure the soundness of markets. As we will discuss below, there are a number of areas of contemporary American law which already apply this enterprise analysis, particularly those which regulate the modern economy.

The transition to this new enterprise analysis will be demanding for legal thinkers and decision makers. To decide the scope of legal responsibility within a business enterprise, courts, agencies and legislatures will have to determine the underlying policies and objective of the specific area of law involved. They will then have to consider whether, in the light of the business contours of the enterprise, the law's objectives are best served by application of the law to the entire group of corporations conducting an integrated business enterprise under common control, or by resort to traditional entity law which looks solely to the legally separate corporate subsidiary directly involved in the particular activity in issue. For example, to determine parent company liability for environmental cleanup, the decision maker will have to understand the economic reality of the enterprise on the one hand and the policy needs of the environmental law at issue on the other. While this demands more than traditional "veil piercing" or other rules which look 
exclusively to corporate structure, the standard is straightforward to apply. ${ }^{12}$ Finally, by doing so, the legal decision makers are directing their attention in this analysis to the question facing them: which approach — enterprise or entity_will better implement the underlying policies and objectives of the law in the particular area, and not subject those policies to ready evasion by manipulation of the corporate structure. By asking the right questions, the chances of developing sound answers are dramatically improved.

At the beginning, application of enterprise analysis rather than automatic use of entity law with its confusing corollary of "piercing the veil" will be a challenging change from unreasonable rules to unruly reasonableness. However, one can be reassured by the reality of past experience. Looking broadly over the landscape of American law for the last 100 years, we find many examples of legislatures, administrative agencies, and courts using functional enterprise analysis to get better answers and achieve fuller realization of the goals of the law at issue. While these examples have not articulated a sophisticated theory of enterprise analysis, they do make very clear the overriding importance of such factors as "control" and economic integration in determining the contours of the enterprise and the pursuit of legal policy goals. This history, while necessarily piecemeal and uneven from the perspective of the whole legal system, shows that the general use of enterprise analysis in legal decision making, which is already demonstrated in so many areas, is achievable and desirable.

\section{EXAMPLES OF ENTERPRISE ANALYSIS IN US LAW.}

Enterprise analysis requires us first to escape the conceptual blinders of the traditional theory that each individual legal corporate subsidiary is a separate entity. The traditional theory of corporate separateness has two grave weaknesses. First, it is simply not an accurate description of economic reality for the separate corporations which make up the modern large business enterprise. Further, as a pragmatic matter, a blind focus on each subsidiary as a separate corporation inevitably opens the door to ready evasion of the legal policy in issue by using the subsidiary to conduct the activity of concern. There are many examples of decision makers using functional enterprise analysis to remove the conceptual blinders of the outdated historic doctrine (Strasser and Blumberg, 2007). Many come from modern business regulatory systems.

\footnotetext{
${ }^{12}$ Of course, one must recognize that the claimed clarity of traditional veil piercing rules is largely a myth. As discussed above, the day to day reality in the courts is a picture of ill considered uncertainty and ambiguity. See authorities cited supra n. 4 .
} 


\section{A. Securities Regulation.}

Consider, for example, the U.S. regulation of issue and sale of securities which began in earnest with the "new deal" in the 1930's. The regulatory system was set up to cure rampant speculation and fraud in securities issue and trading, and thereby to stabilize the underlying securities markets. Effective regulation of securities issuers, securities traders, and securities markets was the only way to protect investors. Yet, to have effective control, regulation had to reach the whole issuing and trading enterprise, not just some of the nominally separate subsidiaries. It found the concept of "control" as the legal tool to accomplish this.

In the regulatory system which was established, the regulatory restrictions reached across traditionally separate corporate entities to regulate all that "control, are controlled by, or are in common control with" the regulated corporation. ${ }^{13}$ This was the way to regulate effectively the whole securities business enterprise. Such a broad reach over the whole enterprise is necessary to achieve the statutory objectives--protecting investors and regulating securities markets. Otherwise, fraud or other improper behavior could be done by a corporate subsidiary of the issuer which, because it was a legally separate corporate entity, would not be subject to the regulatory controls, although the negative effects on securities transactions and securities markets would be the same. Effective regulation requires coverage of the whole enterprise, with, once again, little or no role for traditional entity law, limited liability and veil piercing. ${ }^{14}$ This is a clear application of enterprise analysis. Law reaches the whole enterprise here because it must do so to be effective in accomplishing the policies and goals of the securities law. Similar regulatory structures using enterprise analysis and resting application of the regulatory program on "control" have been adopted for regulation of many other aspects of financial services business, most notably the banking, savings and loan, investment company, and insurance industries.

\section{B. “INTEGRATED ENTERPRISE” DOCTRINE IN LABOR LAW.}

American labor law offers another example of enterprise analysis in its "integrated enterprise" doctrine. The example is particularly interesting because the doctrine was originally developed by an administrative agency, the National Labor Relations Board, to make the law's core regulatory protections effective; it has since been embraced by Supreme Court and adopted by Congress in other labor relations statutes.

\footnotetext{
${ }^{13}$ The regulation of an issuer of securities which also extends to "any person directly or indirectly controlling or controlled by an issuer, or under direct or common control with an issuer" (U.S.C. 15, 2000; Blumberg et al. 2005,chap. 118, §118.02).

${ }^{14}$ For a discussion of the limited role of veil piercing in this area, see Blumberg et al. (2005, §118.10[B]).
} 
When first developed, the doctrine was needed to enforce the labor law obligation of an employer to bargain with a labor union which represents a majority of its employees. To evade this obligation, an employer presented with proof of representation could simply incorporate a new subsidiary, shift the work to it, and then the union would have to start all over again securing representation rights from those employees. While the new subsidiary would doubtless be a formally separate corporate entity, it would also certainly be part of the same business enterprise using a different corporate vehicle to conduct business. To prevent this corporate slight of hand by the strategic use of corporate subsidiaries, the National Labor Relations Board formulated the "integrated enterprise" doctrine. (Blumberg et al., 2005, §103.5 et. sec). Under this doctrine, two affiliated corporations may be treated as a "single employer" for purposes of determining the scope of the duty to bargain under the Act. The doctrine considers four factors: whether between the corporations there is: "(a) interrelationship of operations; (b) centralized control of labor relations; (c) common management; and (d) common ownership and control" (National Labor Relations Board, 1956). With the subsequent approval of the Supreme Court, this doctrine has become a foundational concept in federal and state labor relations law (Radio \& Television Broadcast Technicians Local Union v. Broadcast Serv. of Mobile, Inc., 1965).

The doctrine originated as an administrative agency rule adopted to regulate labor relations effectively, but with its subsequent judicial approval, it has been adopted to serve the same important role under a series of federal statutes in the employment and discrimination area. These include the Age Discrimination in Employment Act, the Americans with Disabilities Act, and the Equal Pay Act (Blumberg et al., 2005, $\S \S 105.01,105.03,110.04)$. The doctrine has been further extended to assure extraterritorial application of employment discrimination acts to protect Americans employed abroad by the foreign affiliates of American-based corporate groups (Public Law No. 102-166, 1991; Blumberg et al., 2005, §105.03).

The "integrated enterprise" standard was formulated and has been employed for use in the application of federal labor, employment, and discrimination laws. It is a labor law doctrine, focused primarily on the degree of integration of the labor and employment management within the enterprise, rather than on extent of managerial and operational integration or the exercise of "control" in other areas. As a labor and employment law doctrine, its application should be determined by employment law policies; the use of enterprise principles in other legal areas should, accordingly, be governed by their policies. This is clear enterprise analysis. The administrative agency, and eventually the courts and congress, crafted a legal doctrine for labor law's application to the entire business enterprise, based on the needs of implementing fundamental labor policy. Enterprise analysis teaches us to look to the underlying body of law giving rise to duties and rights, here labor law, to determine that sound labor policy requires law to look to the whole enterprise. The resulting "integrated enterprise" doctrine in labor law is good labor law policy, based on a sound enterprise analysis. 


\section{Corporate TAX LaW}

US federal tax law offers an intriguing mix of enterprise analysis and entity elements which coexist in a system in which their combination makes for exquisite complexity. Our purpose in this discussion is to review a few examples of enterprise analysis within the system (Blumberg et al., 2005, chaps. 132-137). The tax system reflects its historical roots in its firm commitment to entity law by specifying that each formally separate corporation is a separate taxpayer (Blumberg et al., 2005, §132.01). Of course, such an approach could be manipulated strategically by a taxpayer to shift income, deductions, and other aspects of taxation to the most advantageous entity within the enterprise. The tax law responds with a large number of quite complex provisions, all themselves based on enterprise analysis, which prescribe how income and deductions are to be calculated so as to prevent such abuse. This is, in essence, an enterprise analysis core in a nominally entity based system. ${ }^{15}$

As long ago as 1916, the tax drafters recognized that the revenue producing objective of the corporate tax law would be frustrated if tax law utilized any standard of tax liability that was formal, and thus could be readily avoided by corporate restructuring. Thus the Revenue Act of 1916 turned to the functional standard of "control" to assign tax responsibility in accordance with economic realities. This was enterprise analysis and its development was in significant part the model for overriding traditional legal concepts to achieve functional results that has been adopted in many other areas.

For example, special rules apply enterprise analysis to prevent tax abuse within the enterprise by disallowing losses on transactions between its different parts. Without such controls, losses could be generated by easily arranged intragroup transactions, and the result would be to move income to the corporate entity which could give it most favorable tax treatment. The core rule here, in section 482 of the Internal Revenue Code, states:

In any case of two or more organizations, trades or businesses, owned or controlled directly or indirectly by the same interests, the Secretary [of the Treasury] may distribute, apportion or allocate gross income, deductions, credits or allowances between and among such organizations. . . [as] necessary in order to prevent evasion of tax or clearly to reflect the income of any of such organizations. . .(Internal Revenue Code §482; Blumberg et al., 2005, §133.02[E] et. sec)

This section is then implemented by a quite thorough and complex group of regulations. The goal is to protect the integrity of the tax system by authorizing reallocation of income or deductions within the corporate group as necessary. With such a clear focus on the needs of the tax system, this is enterprise analysis. The goal is further supported by a specific provision which defers recognition of losses incurred in transactions with corporate affiliates; this

\footnotetext{
${ }^{15} \mathrm{We}$ do not mean to suggest that the system is always well designed to achieve its enterprise goals. For example, the US internal Revenue Code uses nine different tests for determining when one corporation controls another (Blumberg et al., 2005, chap. 134).
} 
provision was adopted in 1984 to fill a gap in previous law which had received inconsistent treatment in the courts (Internal Revenue Code \$267, Blumberg et al., 2005, §133.02). The rationale here is again clear enterprise analysis. Affiliated corporations are part of the same business enterprise, although they are formally structured into separate corporations, and the income tax liability of that enterprise should not be affected by internal transactions within it.

In a similar fashion, there are specific prohibitions on splitting a business up into multiple separate corporations simply to achieve a tax advantage (Blumberg et al., 2005, §133.03). The tax advantage most likely at issue today is pursuit of increased accumulated earnings allowances, although this is most frequently a problem with smaller businesses and not with public held companies. Yet the enterprise principles used here also justify positive tax treatment as well. While the detailed rules are complex and beyond the scope of this paper, the general principle is that a business can accumulate earnings sufficient to meet the reasonably anticipated needs of the business. Where the business is organized with a parent and separate subsidiary corporations, in general the parent can accumulate earnings sufficient to meet the needs of the subsidiaries as well as itself (Blumberg et al., 2005, §133.04[D]). ${ }^{16}$ Here treating the whole enterprise as one business both reflects economic reality and affords more favorable tax treatment.

A few other examples of enterprise analysis affording more favorable tax treatment are instructive. If the enterprise chooses to restructure, it will often form new subsidiaries, dissolve old ones, and shift assets and operations among the existing ones. In a purely entity based system these would be occasions to realize taxable gains or losses, although they are not really taxable events but only changes in the business' formal structure. The tax law provides that "certain transactions involving changes in the composition, assets, and structure of corporate groups do not give rise to recognition of gain or loss. These relate to transfers of property as well as of stock" (Blumberg et al., 2005, §133.05[A]). The policy is that these changes are internal to the business, and thus not a real third party transaction which should have tax consequences. The specific rules in this area govern reorganizations, redemptions and liquidations; they are quite complex and their technical detail is once again beyond the scope of this paper.

In all of these areas, general principles of enterprise analysis require exceptionally detailed rules and regulations to implement, a result of trying to honor enterprise analysis within a system which nominally recognizes the separateness of corporate subsidiaries. A potentially simpler alternative is to do away with such recognition all together and tax the whole group of corporations as one enterprise with one consolidated tax computation. Such consolidated reporting is permitted under special sections of US Tax law for enterprises which elect to use it (Blumberg et al., 2005, §133.07). ${ }^{17}$ The leading American tax treatise comments:

\footnotetext{
${ }^{16}$ While the policy justification would apply equally to accumulating the earnings in a subsidiary rather than in the parent, the law is less clear in authorizing this.

${ }^{17}$ The election can be made only for tax computation of domestic corporations in the corporate group.
} 
The basic concept underlying these provisions is that the consolidated group constitutes, in substance, a unitary economic enterprise, despite the existence of technically distinct legal entities; as such, its tax liability ought to be based on its dealings with outsiders rather than on intragroup transactions. The unitary enterprise concept lies at the heart of the treatment, both past and present, of intracompany transactions which, in general, are eliminated in computing the group's consolidated taxable income" (Bittker \& Eustice, 2002, pp. 13-112).

This is, of course, enterprise analysis. Using it in this comprehensive way avoids many of the complications of adapting an entity-based system to enterprise realities.

\section{JURISDICTION AND PROCEDURE}

In addition to legislative and administrative illustrations of use of enterprise analysis in American law discussed above, the law of judicial jurisdiction and procedure also provides illuminating examples. Outstanding examples are the development of the "stream of commerce" doctrine in jurisdiction and the doctrines of "discovery" and res judicata in procedure. These examples further illustrate the richness of enterprise analysis. As we will see, "stream of commerce" like its companion doctrine in tort law, product liability, rests on economic integration without regard to "control" while discovery and res judicata rest on "control' without regard to economic integration.

The "stream of commerce" doctrine is concerned with bringing a remote corporation under the jurisdiction of a local court because the corporation has been selling its products in the jurisdiction through a subsidiary or other affiliated entity. In the simplest and most traditional fact pattern, the remote corporation is a parent and the local selling entity is a subsidiary, although as the doctrine has developed, this structure is relevant but not determinative in finding jurisdiction. "Stream of commerce" jurisdiction is a growing, developing doctrine and its requirements are still being specified, so a precise statement would require a greater treatment that is warranted here (Blumberg et al., 2005, $\S \S 30.02$ et. sec). In broad outline, the doctrine finds jurisdiction in the local forum when the remote company reasonably anticipated such local sales and purposefully pursued access to the local forum's market. The core policy justification is to make amenability to jurisdiction, and thus to potential liability, extend to the expected geographic reach of the product's distribution; in this regard, it is the procedural analogue of modern products liability law and policy. The doctrine has been widely embraced by the US federal and state courts in the last 30 years and it continues to grow. ${ }^{18}$

\footnotetext{
${ }^{18}$ See Blumberg et al. (2005), at $\S \S 30.03$ and 30.04 (federal cases), 30.05 (state cases), and 30.07 (exceptions).
} 
As noted above, the doctrine originated in cases involving remote parent manufacturing companies and local distributing and sales subsidiaries. However, the policy justification has shifted from this implicit emphasis on control over corporate subsidiaries, and the cases today turn on economic integration--access to and exploitation of the local market by the remote parent-whether this is done through a subsidiary or a separate company not owned by the parent. The remote parent's reasonable expectation of sales in the forum is a key part of the analysis, although some formulations add a requirement that the parent have engaged in conduct which was aimed at the forum's market. ${ }^{19}$ Regardless of the formulation given the doctrine in a particular jurisdiction today, a parent-subsidiary relationship is not required, although where there is one, this will usually supply the facts to find jurisdiction under the doctrine. ${ }^{20}$ The most important issues in the continuing development of the doctrine are a more precise formulation of what is required in addition to anticipated sales, as well as the question of jurisdiction over third party makers of component parts of the product. ${ }^{21}$

"Stream of commerce" jurisdiction is enterprise analysis, as shown by two central characteristics of the doctrine's development. First, the doctrine is based on the law's policy to reach both producer and seller in the modern global economy in which production, distribution and sale will often take place in different state and national jurisdictions. The doctrine has developed in response to society's need to have jurisdiction follow the product's market exploitation. Second, the enterprise nature of the doctrine is shown clearly in what it does not consider. The idea that a manufacturing parent and a distributing or selling subsidiary are nominally separate corporations is not even part of the modern discussion of the doctrine. Indeed, the doctrine is an expansive one which goes beyond the corporate groups idea of enterprise, extending as it does to entities which are truly separate legal entities, where their cooperation in the production-distribution chain is evidence of a degree of economic integration. Thus this enterprise analysis is based on economic integration and contemporary social needs alone, without even the traditional element of legal control.

\footnotetext{
${ }^{19}$ In a key Supreme Court case, the Court embraced the doctrine but found it inapplicable to the facts before it because the remote entities, here an independent secondary distributor and an independent retailer, had not sought to serve the market of the local jurisdiction (World-Wide Volkswagen Corp. V. Woodson, 1980).

${ }^{20}$ See Warren v. Honda Motor Co. (1987) in which the court reached not only the remote parent, but also its research and development subsidiary because the subsidiary's activities had been an important part of a "joint effort to place a certain product in a worldwide market."

${ }^{21}$ See Asahi Metal Indus. v. Superior Court (1987). In a case marked by a number of opinions, the Court held that the doctrine did not authorize jurisdiction over an unrelated component manufacturer of the parent company's product (the parent, although remote, did not contest jurisdiction). While eight members of the Court agreed on the applicability of the stream of commerce doctrine as stated in the World-Wide Volkswagen cases, a majority of the justices could not agree on the nature of the "purposeful availment" element. For a discussion of additional limitations, see Blumberg et al. (2005,_\$30.06).
} 
Our second procedural law illustration concerns the law of discovery; as noted above, here enterprise analysis rests on control, in order to achieve the policies of the procedural law at issue. In general, in US litigation, parties are required to give their opponents relevant information about the dispute when asked, "if available" for documents or if subject to the party's "control" for interrogatories. The core policy is that, with this discovery, the outcome of the litigation will then be based on the facts, and concealment of them will be much more difficult. Production of specific information is required when the court, exercising its discretion, determines that the information is relevant and important. The question of concern here is whether, in litigation against a parent company, the parent must supply information about its non-party subsidiary.

In answering this question, courts have not considered the formal corporate separateness of the subsidiary, but rather have examined whether the parent actually controls the subsidiary, and thus whether the information is "available" (Blumberg et al., 2005, §37.03[C] and [D]). The decisions do not consider traditional notions of subsidiaries as separate entities, nor notions of "piercing the veil", but rather use the general doctrine which applies to all other discovery orders. Courts generally apply the same rules when determining whether a party subsidiary must give discovery about its non-party parent, although there are some isolated exceptions (Blumberg et al., 2005, §37.04). ${ }^{22}$ This is, once again, enterprise analysis, looking to the policies and rules of procedural law to decide this procedural question. As such, it is good procedural law and policy and thus good corporate law as well.

Our third example from the area of jurisdiction and procedure is the doctrine of res judicata which can apply to preclude a party making a claim or defense (Strasser \& Blumberg, 2007, pp. 37-44). The doctrine is concerned with when a judgment against one party will be applicable to another party. Under this doctrine, many courts have held one corporation bound or protected (as the case may be) by a judgment for or against another corporation on a closely related claim or defense, where the corporations are parent and subsidiary corporations. In these cases, enterprise analysis starts with the underlying policy of the doctrine--that the legal system need afford only one "full and fair opportunity" to litigate a matter or issue. Application of enterprise principles supports the recognition that the purposes of the doctrine are fulfilled when the parties in question are linked by "control". In the same fashion, the corollary doctrine of collateral estoppel (issue preclusion) applies to bar a second litigation over a closely related issue already determined in an action involving a closely related party such as a parent or subsidiary corporation.

These examples from the law of jurisdiction and procedure illustrate specific applications of enterprise analysis to effectuate the policies of the area of law at issue. On examination, one finds a similar, although highly selective, use of enterprise analysis even in a body of law, contracts, which is nominally ruled by traditional entity principles.

\footnotetext{
${ }^{22}$ This is also true of transnational discovery (Blumberg et al., 2005, §37.05[C]).
} 


\section{E. SELECTIVE USE of ENTERPRISE ANALYSIS In ENTITy LAW: AN EXAMPLE FROM CONTRACTS}

In a typical contracts case involving corporate groups, a contracting party seeks to hold the parent company liable for the contractual obligations of its subsidiary (Strasser and Blumberg 2007, pp. 37-44). Enterprise analysis here should focus directly on the most basic contracts policy question: Did the contracting party get the deal it made, including the performance it reasonably should have expected? If the deal was with the subsidiary, the court should not extend liability to the parent for doing so would give the contracting party more than it bargained for in the contract. The policy of the law should be to assure that the contracting party received its expectations from the contract. However, if the contracting party did not get the deal and the performance potential for which it bargained, then contracts policy calls for relief.

In one group of contracts cases, the decision turns on whether the subsidiary or the parent misrepresented the identity of the contracting party or the obligations undertaken, for example by representing that a contract with the subsidiary was being made with the much larger parent. Where there has been such misrepresentation, relief is typically granted (Blumberg et al., 2005, $\S 69.04$; Strasser, 2005, pp. 650-56). Yet where no misrepresentation has been shown, fundamental contracts policy does not call for parent company liability. Consider the case of creditors who choose to deal with the subsidiary in the face of either a parent company refusal to guarantee the obligation, or a refusal to supply financial information (Blumberg et al. 2005, $\S 69.04[\mathrm{~B}])$. The rationale here is that the creditor got the deal it made, with the party it chose to deal with, and consistent with good contracts policy, the courts should not substitute a better deal. In these cases, the courts do not use the language of enterprise analysis, but rather use the traditional jargon of "piercing the veil". However, the results are, in substance, consistent with enterprise analysis. $^{23}$

Norhawk Inv. v. Subway Sandwich Shops, Inc. (1991) is a clear if extreme example. Subway Sandwich Shops, the parent, set up a local subsidiary corporation and used it to lease real estate from the Plaintiff Norhawk; the property was then subleased to a franchisee. The local Subway lessee subsidiary had no assets, employees, or bank balance and had been deliberately undercapitalized. When the franchisee sublessee failed, Norhawk sought relief from the parent Subway. In denying recovery, the court emphasized that the parent had been quite clear that Norhawk was contracting only with the local subsidiary, relying only on its promise and credit; further, the parent had insisted on its policy of not disclosing financial information about either the parent or the subsidiary. Indeed, the parent Subway had made plain that it would insist on its nondisclosure policy and abandon the lease transaction rather than disclose the information

\footnotetext{
${ }^{23} \mathrm{We}$ do not mean to suggest that veil piercing law typically reaches results consistent with good enterprise analysis, for it most assuredly does not in most cases. This contracts situation is an untypical application of veil piercing, one which requires considerable straining of the doctrine to reach this result.
} 
sought. When Norhawk went ahead and leased to the subsidiary in this situation, the court reasoned, it took the risk of dealing with a very thin subsidiary. When this risk eventually materialized, and the thin subsidiary was unable to pay the lease, the court was unwilling to give Norhawk a better contract than the one it agreed to and held that the parent was not liable for the subsidiary's lease obligation.

The result, while admittedly based on extreme facts, is good contract law policy and, for this reason it is a good result consistent with enterprise analysis. The decision to extend contract liability to corporate parents should be informed by contract policy, not by abstract doctrines of corporate separateness or wrongdoing that are at the heart of the traditional veil piercing. Those traditional corporate doctrines, if applied here, could have justified a different result, for the subsidiary was not in fact a separate operating entity. ${ }^{24}$ However, such a result would be bad contracts policy and, thus, inconsistent with enterprise analysis. There are similar cases that also reach good contracts policy results in the face of traditional veil piercing factors such as lack of separate existence, undercapitalization, failure to comply with corporate formalities, and extensive economic integration. (Blumberg et al. 2005, §69.04[B][1]-[4]) While these cases are at odds with mainstream veil piercing doctrine as conventionally articulated, they are able to strain and stay nominally within the doctrine by exploiting its imprecision and ambiguity to reach good contract policy results, consistent with enterprise analysis. In these admittedly unusual cases, we find de facto enterprise analysis hard at work to fill the space left by the doctrinal vagueness of traditional veil piercing.

\section{WHY A GENERAL THEORY OF ENTERPRISE ANALYSIS?}

The examples above, and other more developed work by the authors, Strasser and Blumberg (2007), show that American law has been able to surmount the blinders of traditional corporate law theory and apply enterprise law in some places where it was needed. Do they also show, then, that a more general theory of enterprise analysis is not needed because the problem it addresses-inappropriate use of corporate entity law to determine legal rights and duties in enterprises made up of many corporations-has already been satisfactorily resolved. Can we say that the legal system, having successfully moved beyond the restrictions of entity law in these examples, can reasonably be expected to do so in others when this is needed. We will argue that this view is too optimistic and that a general theory of enterprise analysis is needed.

Most fundamentally, a theory of enterprise analysis is needed to counteract the legal thinker's ingrained tendency to yield to the seduction of traditional concepts of corporate separation and "veil piercing". These concepts are deeply entrenched in the legal mind, taught in all core business law courses, and accepted unquestioningly in most legal analysis concerned with the

\footnotetext{
${ }^{24}$ Traditional veil piercing law might have found no reason to pierce if it determined that there was no wrongful conduct, although the undercapitalization and commingling of assets would be sufficient wrongful conduct for many courts applying traditional law.
} 
issue. At a minimum, a conceptual alternative is needed to break this cycle of unconsidered, automatic acceptance. As matters stand now, enterprise analysis is most often used not when traditional theories are considered and rejected, but in regulatory and public policy situations where effectiveness demands it and reliance on corporate separateness would be manifestly dysfunctional. Thus, use of de facto enterprise analysis is typically based on the policy of the area of law under consideration, but not on a conscious rejection of traditional corporate law's separate entity concept. In situations where the traditional theory appears to be attractive, another theoretical alternative is needed to start the analytical process. As the discussion of the unfortunate opinion in Bestfoods above shows, traditional models can be very hard to escape even where they don't fit.

Further, without a general theory, lessons learned in applying enterprise theory in one legal area will not be generalized and thus they we lose the chance for them to be useful sources of learning in other areas. For example, labor law's "integrated enterprise" doctrine is based on the needs of the regulatory and other policy in the area under consideration-labor law--yet it supplied no conceptual support for adoption of enterprise analysis in financial services, even though the abstract regulatory policy problem was conceptually the same. In each area, the enterprise analysis wheel had to be completely reinvented. Not only does this demand more intellectual resources, but it increases the chances for a breakdown in the invention process and a default to inapplicable traditional models.

As we have seen, the enterprise analysis to be applied is a general theory of how to approach the problem. It says, first, look to the reality of the business enterprise presented. Separate corporations under common control are presumptively operating one business enterprise and should be thought of as such. This is the starting point, but the analysis then goes further. Does unitary treatment for the whole corporate group, the enterprise, makes sense in view of the legal rules, principles and policies at stake. In our examples, we see that often such treatment does make sense. However, this is not always the case, as we saw in the contract liability discussion. Enterprise analysis is concerned with the implementation of the underlying legal policies in the resolution of the particular dispute before the court. In consequence, its outcome will be highly selective. Enterprise analysis calls for further thinking, not an automatic application of enterprise law.

Finally, a general theory will assist the process of developing reasonable rules to provide guidance and fill in the details for specific situations. As enterprise analysis is applied to more and more situations, the accumulated results and the experience of reaching them will inform decision makers and make the next application of it better informed, as well as more familiar. This process will be enhanced by a general theory of enterprise analysis, where the lessons from one legal subject matter area, such as labor law, can offer guidance in another, such as securities regulation. 


\section{CONCLUSION.}

We argue that the law should move from outdated entity rules to enterprise analysis. As we have seen, the law, despite its continued addiction to the historic doctrine of entity law has, almost in spite of itself recognized the wisdom of applying enterprise principles in numerous areas. Notwithstanding these advances, the law, particularly judge-made or common-law decisionmaking, is still in a relatively early stage of development and further growth is needed. Enterprise analysis, applied as a rigorous, disciplined doctrine, should be the guiding concept for that development. As stated, enterprise analysis has two fundamental parts. First, it requires a disciplined identification of the underlying policies of the law in the specific area of the law at issue, policies that will be either implemented or frustrated by the decision at hand. Second, it involves a careful review of the specific facts in the matter under consideration to determine the economic contours of the business enterprise involved. The primary focus of this review will be on the realities of control and the degree of economic integration of the business of the group. Such a review will be further illuminated by considering further dimensions of integration of the group such as financial interdependence, administrative interdependence, group-wide personnel integration through common assignment and compensation policies, and a common public persona of the companies comprising the group.

In the light of these economic realities of the business enterprise, the decision maker should then determine whether the application of enterprise principles or ancient entity law better achieves the objectives of the law in the area. Doctrinal universality without regard either to the objectives of the law in the area or to the economic contours of the enterprise has made entity law dysfunctional and an anachronism with respect to the modern large corporation. In contrast, enterprise analysis is highly selective in its search for the development of a new legal system to serve the new business society. 


\section{BIBLIOGRAPHY}

15 U.S.C. $77 b(3)$ (2000).

Antunes, J. (1994). Liability of Corporate Groups: Autonomy and Control in Parent-subsidiary Relationships in US, German and EU Law. Kluwer.

Asahi Metal Indus. v. Superior Court, 480 US 102 (1987).

Bainbridge. (2001). Abolishing Veil Piercing. Journal of Corporate Law, 26, 479.

Bittker \& Eustice. (2002), Federal Income Taxation of Corporations and Shareholders_( $7^{\text {th }}$ ed.).

Blumberg, P. (1993). The Multinational Challenge to Corporation Law: The Search for a New Corporate Personality.

Blumberg, P. (2005) The Transformation of Modern Corporation Law: The Law of Corporate Groups. Connecticut Law Review, 37, 605.

Blumberg, P., Strasser, K., Georgakopoulos, N., \& Gouvin, E. (2005). Blumberg on Corporate Groups. Aspen.

Dodd, E. (1960). American Business Corporations until 1860.

Muchlinski, P. (2007). Multinational Enterprises and the Law (2nd. ed.). Oxford.

Easterbrook, F., \& Fischel, D. (1985). Limited Liability and the Corporation. Chicago Law Review, 52, 89.

Hansmann, H., \& Kraakman, R. (1991). Toward Unlimited Shareholder Liability for Corporate Torts. Yale Law Journal, 100, 1879.

Hansmann, H., \& Kraakman, R. (2000) The Essential Role of Organizational Law. Yale Law Journal, 110, 387.

Internal Revenue Code, §267.

Internal Revenue Code, $\S 482$.

National Labor Relations Board. (1956) NLRB Annual Report, 21, 14.

Norhawk Inv. v. Subway Sandwich Shops, Inc. 61 Wash. App. 395, 811 P. 2d 221 (1991). 
Pub. L No. 102-166, §109, 105 Stat. 1071 (1991).

Radio \& Television Broadcast Technicians Local Union v. Broadcast Serv. of Mobile, Inc., 380 U.S. 255 (1965).

Ribstein, L. (1991). Limited Liability and Theories of the Corporation. Maryland Law Review, 50,80 .

Schenley Distillers Corp. v. United States, 326 U.S. 432 (1946).

Strasser, K. (2005). Piercing the Veil in Corporate Groups. Connecticut Law Review, 37, 637.

Strasser, K., \& Blumberg, P. (2007, July 20-21). Replacing Misused Limited Liability With Enterprise Analysis In Corporate Groups. Paper presented at the Conference on Corporate Accountability, Limited Liability, and the Future of Globalization, School of Oriental and African Studies, London, UK.

United States v. Bestfoods, Inc., 524 U.S. 51 (1988).

United States v. Elgin, Joliet and Eastern Railway, ${ }^{* *}$ U.S. 442 (1996).

United States v. New York Tel. Col, 326 U.S. 638 (1946).

Warren v. Honda Motor Co., 669 F. Supp. 365 (D. Utah 1987).

World-Wide Volkswagen Corp. V. Woodson, 444 U.S. 286 (1980). 